\title{
Propria Delicht On Indonesian Financial Policy Relating To Covid-19
}

\author{
Retno Dewi Pulung Sari ${ }^{1}$ \\ ${ }^{1}$ Universitas Katolik Darma Cendika, Surabaya, Indonesia \\ E-mail: retno.dewi@ukdc.ac.id
}

\begin{abstract}
The government acted swiftly by issuing Law Number 2 of 2020 concerning the stipulation of Government Regulations in lieu of Law Number 1 of 2020 concerning Financial Policies and Financial System in handling Pandemic Corona Virus Disease 2019 (Covid-19) an / or in Order to Face Threats which Endangers The National Economy and / or The Stability of The Financial System into Law. However, this Law is controversial because of the existence of article 27 of the regulation which contains a clause regarding impunity for certain officials mentioned in that article. This is a such a problem when the actions carried out by state officials constitute offense propria delicht. Based on these problems, it could be concluded that officials who are proven to have the intention (mens rea) to make mistakes by taking advantage must be punished. The pusnishement that given must alsohave an addition because the perpetrator is an official who should have more rsponsbility than ordinary people. Research method uses a statutory approach and conseptual approach related to research discussions related to proprian offense in Indonesia's financial policy related to Covid-19.
\end{abstract}

Keywords- Impunity; Propria; Mens Rea; Criminal Policy

\section{INTRODUCTION}

Almost the whole world is suffering from the Corona Virus or what is commonly reffered to as Covid-19. Even though there are some countries has almost ended the Covid Pandemic, Indonesia is still trying hard to solve it. Until now, several areas in Indonesia there are none of infected people. But few of big cities are still struggling to minimize the number of positive Covid-19 patients who have died. This process cannot be separated from the active role of the government in carrying out the process of prevention and control simultaneously. The basic effort is to issue regulations that could become the basic for the government to move providing assistance for the people which due to large-schale social restrictions causes suffer for the community because their work cannot be done. People who are directly or indirectly affected need assistance will automatically use the costs from the state budget or regional expenditure budgets. Many of government agendas that must be work out with the 2020 national government budget have to be postponed and transferred to the community as the implementation of the law. Very large trasnfers of funds must be balanced with the targeted results including an appropriate process. The governments has the authority to make budget trasnfers for very sensible reasons. Authority is a definition derived from the law governmental organizations which can be explained as all of the rules relating to the acquisition and use of government authority by public legal subjects in public legal relations [1].

Based on Law Number 6 of 2018 concerning Health Quarantine, the government issued Government Regulation Number 21 of 2020 concerning Large-scale social Liberation (abbreviated as PSBB) in order to accelerate the handling of the corona virus disease (covid-19) on March $31^{\text {st }}$, 2020. This Regulation was issued with the intention of the transmission of the Covid - 19 Virus can be suppressed because there is no movement of people in schools, at work or restaurant / café, market, wherever there is human movement. To follow up on PSBB rule, the government has issued Law Number 2 of 2020 concerning stipulation of regulation in Lieu of Law Number 1 of 2020 concerning Indonesia Financial Policy and Financial System Stability for Handling Corona Virus Disease 2019 Funding in the context of dealing with dangerous threats. National Economy and /or Financial System Stability Become Law which hereinafter will be reffered to as Law concerning financial policy. This Law is a financial policy that made because the government hopes that the socio-economic conditions of the community will be greatly affected by the existence 
of the PSBB. Some companies can still implement work at home, but not all business can run this, so in the end many companies go bankrupt.

The bankrupt company resulted in many workers being dismissed from their places of work so far they no longer work and earn money for their basic dailiy needs. Even though the daily needs are not only for food bur also for health and education. The community still has to bear medical expenses because it is not $100 \%$ protected by the government if Covid-19 is detected. Likewise, children must join with their class from home by relying on applications that require internet data quotas and mobile phones that they can access face to face online meetings conductes by class teachers. Suden financing must be provided by community where they can no longer earn a lot of income because of job termination. Likewise, people who work in the informal sector are very affected because they also rely on service and sales business to workers who work in their respective offices or factories. Workers who have to work at home cause they not to carry out any transactions in their workplace. This has a lasting effect on people who run their businesses linierly with formal jobs. They also do not get income, so they are included in the group that was indirectly affected by the Covid-19 Pandemic. This situation forces the government to issue a financial policy which is thougt to be able to help the situation of the community, which currently still needs assistance or support from all parties. So, The government Regulation number 1 of 2020 was issued which was later stipulated by statutory regulations, namely the law on financial policy.

The government actually has a good policy by making these rules, but there are things that attract the attention of the public with one of the articles contained in Law number 2 of 2020 concerning financial policy. It is stated in article 27 of the Law on financial policies where in paragraph (1) it is written about the costs that have been incurred by the Government and / or the KSSK institutions in the context of implementing revenue policies including policies in the field of taxation, state expenditure policies including policies in the field of regional fiancé, financing policies, financial system stability policies and national economic recovery programs, are part of the economic costs of savig the economy from crisis and not state losses. KSSK is the financial system Stability Committee where the KSSK is a team formed to carry out prevention and resolution of financial system crises to carry out the interests and resilience of the state in the economic sector.

The purpose of law by Radbruch said that contains justice, certainty and benefit must remain the goal of a regulation made for the walfare of the community. As stated by Jeremy Bentham, Henry Sidgwick, and John Stuart Mill in the theory of utilitarianism which state "The Greatest happiness of the greatest number". A situation that is considered an emergency due to covid-19 in Indonesia so that the actions taken by the government in this case are public officials are expected to be of goodness to the people who really need a helping hand from the government. Based on the news [2] the discusses adequancy of the budget disbursed by the government related to the existence of Covid-19 through the state budget, it is very large budget starting from April $1^{\text {st }} 2020$ to June $17^{\text {th }}, 2020$ data. Corruption, so we need to worry that there are still public officials who commit acts of the corrupt category. This concern is further increased when there is a special regulation in Article 27 paragraph 2 of the Law on Financial policies which claims that all executing officials of the financial policy cannot be prosecuted either civil or criminal if their duties are based on good faith and in accordance with the provisions of the regulations legislation. If the official takes legal action, the official will not be prosecuted criminally or civil. Article 27 paragraph 2 of the financial policy provides a continuation of the provisions of paragraph (1), which the implementers of the regulation cannot be prosecuted civil and criminal, at the same time whatever form of action and decision taken based on this regulation is declared not an object of lawsuit that can be filed against state administrative court. All decisions issued by government officials are legal producst that should be sued by communitty when they felt disadvantage. However, this article does not show the same direction as the previous regulation regarding the rights of community to file a lawsuit in the state administrative court if there is a loss from them. 


\section{PROBLEMS}

Seeing the existence of Article 27 paragraph 1, paragraph 2 and paragraph 3 of the Law on Financial Policies based on legal objectives that there must be legal certainty, justice and benefit, this study take the following problems. First, Could the propria delicht be allegedly committed in Article 27 ? and, second Could the alleged propria delicht committed in Article 27 of Law Number 2 of 2020 be held responsible for the crime?

\section{RESEARCH METHODS}

This research is a normative juridical study where use primary legal sources and materials in the form of laws related to the subject matter and secondary sources of law from various literatures and news as reference materials in conducting research. This study uses a statutory approach and conseptual approach related to research discussions related to proprian offense in Indonesia's financial policy related to Covid-19.

\section{DISCUSSION}

The government has carried out its obligation to be present in the problems of its citizens when there are problems that must be faced, especially concerning the wider community. The government's interest in providing assistance is to ease the burden on the community whose economic capacity has decresed due to unemployment. So many layoffs occurred during this Covid Pandemic. Companies that have to comply with the rules. Large-scale social restrictions from the Indonesian government forced them to lay off working employees. The condition of many employees who have to be on vacation has affected the company's finances. Companies who instruct employees to work at home are not only workers able to work from home, because many jobs cannot be done at home. So, gradually, the company is forced to lay off its workers permanently because the company is no longer able to pay for the salary or honarium of workers without adequate income. Even though the government tries to help maintain the stability of worker's lives by ordering companies to continue to pay salaries and holiday allowances, the situation also makes the company unable to withsatand the company's financial capacity which has actually fallen.
Informal workers are also affected, because formal workers become customers they can no longer work as they should. When no one uses their services or buys their merchandise, they are also affected economically. When there has been no movement from the government, people who are more able to able to help by making movements to share goods or food need by the people in their environment [3]. Activities that have an extraordinary impact with the emergence of emphaty for people who desperately need even for their basic needs, namely food. Likewise, the economy of the people from the middle to lower levels began to stretch with the presence of online food sales. The first time ths business appeared because of the need for money for the community. They ventured, and so did the buyers, ventured to buy. Buying not because you want but to help other people who sell.

The government also provides assistance to the community besides in the health sector. As well as in the field of manpower and life in the form of providing basic commodities. To provide such assistance, regulations are needed as a legal basis for the government to divert budgets, because during this pandemic the government stopped using too much of the programmed budget. The budget diversion is used to provide financing for various aspects of life to restore conditions that have worsened due to circumstances. The data released by the Ministry of Finance whichwas submitted by Kompas Dailiy on June 25 $5^{\text {th, }}$ (Patricia, 2020) showed that at the time of the initial handling of Covid-19, namely in mid-march, the funds allocated through the Regional Expenditure and expenditure Budget were in range of 121.3 trillion which increased rapidly in April 2020 to 405.1 trillion [4]. Not long after, on June 3rd, 2020, it was announced that the funds that had been disbursed had become 677,2 trillion Rupiah. As on June $16^{\text {th }}, 2020$, the total use of funds was 695.2 trillion. No more than 2 weeks, the increase was up to 18 trilion. Although the funds used in the APBN are divided for the health sector (87.55 Trillion Rupiah), social protection (IDR 203.9 trillion), business incentives (120 trillion). From this data there has never been an evaluation of the use of Cvod-19 handling funds even though the budget that has been used is already very large. The assumption that the use of the funds was not accurately estimated had occurred, the news 
in the KOMPAS still stated that the absorption of the budget was not clear.

Figure 1

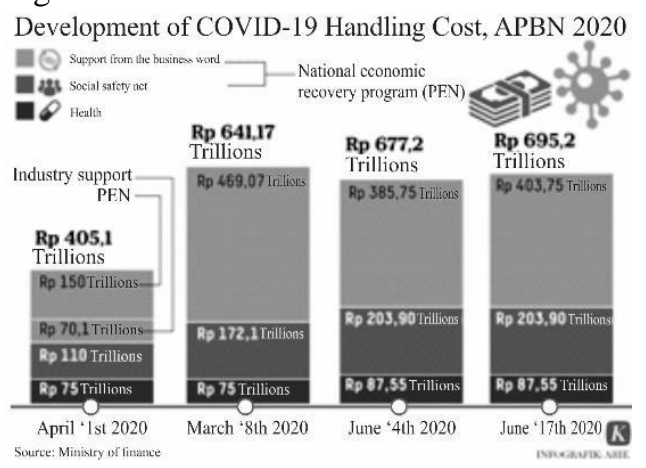

Figure 1 above shows a significant expenditure movement issued by The Ministry of Finance. The report provides financial support for the business world in order to provide a sustainable life for the needs of its workers. The budget spent is mostly for the support of the business world, although health is still a priority, but its absorption has not been as expected. Mahfud MD's opinion quoted by Shandi (Airlangga, 2019) for the concept of power is based on the concept of rule of law, the state in principle is not based on more power (maatschstaat) but must also be based on law. The concept of rule of law often contradicts the concept of a power state or the concept of a state that governs arbitrarily (wilikuurstaat)[5]. Mahfud MD's opinion affirms that the budget provided must be used properly, not only making regulations without clear accountability for use to the community. The power to carry out regulations as aspired by the legislature and government that makes the rules, it is not because like or dislike in authority, the rules must be enforced. In answering the problems in this study, it is divided into 2 (two) discussion sections.

\section{The Alleged Propria offense contained in the Law on Financial Policy}

Article 27 paragraph (1) of the Law on Financial Policy said that the government needs to make financial policies to save the economy so that any action taken by the government is considered an economic cost and not a loss to the state. If it is deemed not to be a loss to the state, than any policy or action taken cannot be said to have caused the state to lose so that it cannot be included in act that violates the Corruption Crime Law. Corruption is a special offense where a general offense is a criminal; act committed by anyone. Meanwhile what is meant by propria delicht is a criminal offense that may only be committed by those who have certain qualities. Delicta Propria or bijzondre delichten has a special character where in this offense, the criminal acts committed can only be committed by people who have the certain characteristic , (Remmelink, 2014)[6]

The Example of legal subject who can commit crimes that fall under the category of propria offenses are people who have certain qualifications such as having power because of their position. Article 27 of the Law on Financial policies clearly shows that every legal subject involved in policies or actions related to the prevention and overcoming of the financial system due to the existence of Covid-19 has legal immunity. Lord Acton's adage that the power to be abused but that unlimited power is abused [5]. This adage may apply today at the time of the implementation of this law on financial policies, because one cannot expect $100 \%$ of each implementer of this policy to do what the government and / or legislators aspire to do. Implementers of Law cannot be taken civil or criminal action, even the legal products they make cannot be used as legal objects for a lawsuit at the state Administrative Court.

When a person has become part of a power, he has a tendency to abuse his power for certain interests, either for the benefit of himself or his group. There are already regulations governing this matter, namely in article 52 of the Criminal Code that an official because of committing a criminal act violates a special obligation of his position, or when he commits a criminal act using his power, the opportunity or means given to him because his position can be increased by one third.

Prior to the issuance of the Law on financial policy, there have been regulations that regulate in a disaster situation, namely in Law Number 32 of 1999 which in article 2 paragraph (2) said that in the case of criminal acts of corruption as stipulated in pharagraph (1) it is carried out in certain circumstances, capital punishment can be imposed. The verse was later changed and then replaced by Law Number 20 of 2001 where in the Constitutional Court decision number 25 / PUUXIV/2016 where 2 paragraph (2) remains as the original content, only there is a clearer explanation, namely what is meant by certain circumstances is a 
situation which can be used as a reason for criminal action against the perpetrator of a criminal act of corruption, namely if the criminal act is committed against funds allocated for handling dangerous situations, national natural disasters, overcoming the consequences of widespread social unrest, overcoming economic and monetary crises, and overcoming criminal acts of corruption. Article 2 Paragraph (2) gives weight to the perpetrator if he commits an act prohibited in Article 2 paragraph (1) during a disaster or crisis situation. Sudarto said that implementing "criminal law politics" means making the choice to create or compile the best criminal legislation on terms of fulfilling the requirements of justice and utility for society. [7]. Officials have an obligation to serve the community, so they are expected to know their competence. All obligations performed by officials are solely for the benefit of the people they serve. When an official does not give what should be done for the community, then the official should be released from his position.

Moreover, if the official is detrimental to the people he serves, then the official should be given heavier sanctions than ordinary people who commit the same crime. The imposition of these sanction needs to be enforced. So there is fear for officials, make them fear to abuse their power. Officials give obligations that should be their job . The politics of criminal law said that the punishment given needs to be weighted because the perpetrator commits a crime that should nor have been committed and prohibited about doing bad things. The intention to commit a crime if proven will receive sanctions for public officials.

Definition power for the public official is to arrange objects according to their will [5] The power possessed by legal subjects as reffered to in paragraph 2 article 27 of 2020 is very large because it has determining factor in policy making. Apart from the government itself, this article contains the KSSK group. The coordinator of the KSSK team us The Minister of Finance and in it there is still the Financial Services Authority Institution, The Governor of Bank Indonesia and all policy holders related to the issuance of this Law. It should be noted that the Government is a state administrator which is a very broad and deep structure due to village / kelurahan administration. Bellow will be explained based on several laws and regulations related to the contents of Article 27 of the Law on financial policies.

Based on the Law of the Republic of Indonesia Number 28 of 1999 concerning the administration of a country that is clean and free from Corruption, Collusion, Nepotism. Hereinafter reffered to as the state administration Law. It is written in article 1 number 1 of the administration law which in the policy saud that admnistrators are public officials who are carring out executive, legislative, or judicial functions and other officials whose main functions and duties are related to state administration in accordance with the provisions of the applicable laws and regulations

The Scope of article 27 paragraph 2 of the Law on financial policies is very broad. Anyone from the government who commits legal actions in running the wheels of government in relation to the Law on financial policies if the policy is wrong. The losses incurred cannot be considered as state losses. Everything related to all functions, both the executive, legislative and judicative, an other officials. All people involved are government administrators.

Likewise in Article 1 of Law of the Republic of Indonesia number 31 of 1999 concerning Eradication of Corruption Crimes, it stated in number 1 that Civil servants include :

a. Civil servants as refered to in the laws and regulations regarding employment

b. Civil servants as intended by the Criminal Code

c. Everyone who receives wages or salaries from money originating from state or regional finances

d. People who receive wages or salaries from the corporation has received money from the state or from regional finances

e. Every person who receives wages or salaries from corporations that get capital or in the form of facilities from the government or even receives from the community.

Even the legal subject is based on Article 1 of Law Number 31 of 1999 which is extended to people who receive wages or receive facilities derivied from state funds. The situation occure as in Article 27 of the law on financial policies can be applied to any person who is referred to as a public servant. Even though they are not appointed as public servants, when they receive the state's money, they get an expansion of legal subjects. Meanwhile, the basic concept of behavior in service 
is the good behavior does not contradict the prevailing norms, so the dedication, loyalty, obedience and discipline, also responsibility are realized based on moral values [8]. Everyone who has good behavior in carrying out duties based on moral values so that they can provide accountability for their work, Even though in the eyes of the law everyone is considered the same, they are not differentiated to obtain legal immunity as said in paragrapgh 2 of article 27 of the Law on Financal policies.

2. Accountability for perpetrators of propria delicht in the Law on Financial Policy

Reffering to the legal immunity or impunity shown in article 27 of the law on financial policy, it is more for officials or related people. Here we will discuss thst impunity can be given to those listed in the rules that apply internationally and nationally. Immunity or legal immunity can be reffered to in international law where the legal immunity only applies to diplomatic officials stationed in a country. Immunity for diplomats is jointly regulated in The Vienna Convention on Diplomatic Relations which applies to countries that have ratified it, including Indonesia. However, specifically for impunity that applies in the country of Indonesia itself, it is stated in Article 50 of The Indonesia Criminal Code which states that the official or person involved in carrying out acts to implement the provisions of the law, is not punished. Even though the bad act is proven, if the act (actus reus) is due to implementing the provisions of the law, the official cannot be held responsible for the crime. However, it will have a different meaning if a will / an intention (mens rea) is found from the action, even though it still has to be proven that this evil intention exists

Propria delicht sees that an act (actus reus) committed by an official is not immediately released if it is detrimental to community, instead there must be a weighting against the criminal sanction. Based on article 363 of the Indonesia Criminal Code. If a criminal act occurs at the time of a disaster, the perpetrator will be subject to heavier than if the criminal act was commited when there was no disaster. Article 362 of the Indonesia Criminal Code states that the criminal penalty for a person who commits theft is a maximum of five years or a maximum fine of nine hundred rupiahs. Meanwhile, the criminal threat of Article 363 of the Criminal Code is more severe for the perpetrator who commits an offense when a disaster occurs or in certain conditions where the owner of the property will definitely lose concentration in supervising his property. The threat of punishment against the perpetrator is a maximum imprisonment of seven years, in contrast to ordinary theft with a maximum of five years in prison. Returning to the intenstion element. The threat of punishmet against the perpetrator is a maximum imprisonment of seven years, in contrast to ordinary theft with a maximum of five years in prison. Returning to the intention element of a criminal act, a person who deliberately commits a crime because he sees an opportunity even when there is suffering or someone else's negligence. The will is intentional (dolus delicht) according to Hazewinkel Suringa[9] where the Will is nothing more than a plan to do the action under certain circumstances in the mind. It also includes a description of how to do it and the consequences that are expected to be obtained even if it is not desired.

Very few books that discuss specifically about propria deicht and even only implied in a few explanations. The discussion only mentions examples of articles in the Indonesia Criminal Code which discuss the propria delicht or offense on position namely in articles 413 - 437 of the Indonesia Criminal Code. For example in article 416 of The Indonesia Criminal Code which said that an official or other person who is given the task of carrying out a public officer continuously or temporarily, who deliberately falsifies or falsifies books or list specifically for administrative examination, will be punished by imprisonment at most four years. This condition shows that in the case of a public official commiting a legal act that violates the rules, there is no legal immunity imposed on the official.

The offense shows that especially for people who have certain abilities, for example because of their position will be subject to a higher penalty because of their knowledge and ability, which is a responsibility that cannot be separated from that position. We know that the Indonesia Criminal Code is a law that regulates crimes and violations committed by Indonesian Citizens. According to Beccaria (Beccaria, 2011)[10] any punishment which does not arise out of absolute necessity is tyrannical. So, on this argument the right 
to punish, that is, for the need to defend the public freedom entrusted to it, from the deprivation of the individual, and that punishment is just in the argument, just as the freedom maintained by the ruler is valuable. Based on Beccaria's opinion, human who because of their position have power over other human beings, must defend the public interest, if they are not based on the public intersest, the actions taken are wrongful.

Through sociological studies to prepare legislation and to regard law as a social institution which can be remedied by prudent efforts to find the best ways to continue and guide such endeavorse. To create effective ways of making laws and regulations and to put pressure on the law to achieve social goals or not emphazing sanction (Madiong, 2014)[11]. The law on financial policy does not emphasize sanctions because it emphasize the social goals that will be achieved by the enactment of these rules. Officials who carry out more courage in carrying out this law for the sake of restoring public finances caused by Covid-19 so that cannot imagine legal snares.

The legal politics of the Law on financial policies have prioritized prevention, mitigation and financial recovery so that with a positive view that everyone will have the same willingness to improve this condition. Minimizing all legal aspects by minimizing the possibility of abuse of power. Barda Nawawi (Nawawi, 2014)[12] offers an integral approach / integral atrategy to avoid corruptive actions or behavior :

1. Not only symptomatic and repressive coping strategies through reform and law enforcement but also causative and preventive countermeasures

2. Not only do the law reform but also in social, economic, political, cultural, moral and administrative reform

3, Not only reforming the corruption law, but also updating all laws and regulations that provide opportunities for corruption / collusion,

\section{REFERENCES}

[1] Ridwan HR. Hukum Administrasi Negara, Jakarta: PT Raja Grafindo Persada, 2013.

[2] A. Theodora and S. Patricia, "Publikasikan Serapan Dana Penanganan Covid-19 secara corruption, nepotism includes, among others, politics, economy, finance, banking, social welfare, professional code of ethics and official behavior, administrative bureaucracy and so on

The legal standing of the government in implementin laws on financial policies must be followed by providing a holistic understanding to the implementers of the rules in order to understand the aims and objectives of these rules as a preventive step. In addition to preventing the funds from being misused, but also so no one will fall into error. So as to lead to criminal responsibility due to a criminal act of corruption caused by intentions (mens rea) and evil acts committed (actus reus).

\section{CONCLUSION}

Indonesia's Financial policy when facing Covid-19 through Law Number 2 of 2020 concerning Financial Policy provides a huge opportunity for governments involved in financial recovery to fall into corrupt behavior. Corrupt behavior in the context of restoring public finances that cannot be considered detrimental to finances policy, cannot even be filed in a civil or criminal case. Even the legal product of the policy cannot be filled as the object of a lawsuit from the government administrative court. The conclusions o f this study are :

1. There is a propria delicht contained in the law on financial policy

2. An analysys of the proria delicht where only people who have the vompetence can commit crimes, in this study it looks more at the elements of officials in carrying out there duties as las enforces on financial policy. It cannot be convicted because of what he did (actus reus) but it must be proven beforehand that there is an evil intention (mens rea) so that criminal responsibility ca be held

Berkala - Kompas.id", Kompas.id, 2020. [Online]. Available: https://kompas.id/baca/ekonomi/2020/06/27/p enanganan-covid-19-minim-transparansipenggunaan-dana-akan-dilaporkan-berkala/. [Accessed: 10- August- 2020] 
[3] K. Utami, "Saweran Masker hingga Rantang Lansia, Solidaritas ala Pantura - Kompas.id", Kompas.id, 2020. [Online]. Available: https://kompas.id/baca/nusantara/2020/04/10/ saweran-masker-hingga-rantang-lansiasolidaritas-ala-pantura/. [Accessed: 10- Aug2020]

[4] S. Patricia, "Penggunaan Dana Covid-19 Belum Transparan - Kompas.id", Kompas.id, $2020 . \quad$ [Online]. Available: https://kompas.id/baca/ekonomi/2020/06/25/p enggunaan-dana-covid-19-belumtransparan/?_t=Xajx0eFAqyfBUcYATHDAB g8kSLzR0f07VXggamZ7UVJ912jGWCJxIei hKx11\#. [Accessed: 10- Aug- 2020]

[5] S. Airlangga, "Hakikat Penguasa dalam Negara Hukum Demokratis", Cepalo, vol. 3, no. 1, p. 1,2019

[6] J. Remmelink, Hukum Pidana, Komentar atas Pasal-Pasal Terpenting dari Kitab UndangUndang Hukum Pidana Belanda dan Padanannnya dalam Kitab Undang-Undang Hukum Pidana Indonesia, Jakarta; PT. Gramedia Pustaka Utama, 2014.

[7] M. Najih. Politik Hukum Pidana, Konsepsi Pembaharuan Hukum Pidana dalam cita Negara Hukum, Malang; Setara Press, 2014..

[8] A. Susanto, "Pemberatan Sanksi Pidana Terhadap Penyidik Polri Yang Menyalahgunakan Barang Bukti Narkotika", Jurist-Diction, vol. 2, no. 1, p. 1, 2019.

[9] Eddy O.S. Hiariej, Prinsip-Prinsip Hukum Pidana, Yogyakarta: Cahaya Atma Pustaka, 2015.

[10] Cesare Beccaria, Perihal Kejahatan dan hukuman, Yogyakarta: Genta Publishing, 2011.

[11] Bass Madiong. Sosiologi Hukum ; Suatu pengantar, Makasar: Sah Media, 2014.
[12] B. Nawawi. Masalah Penegakan Hukum dan Kebijakan Hukum Pidana dalam Penanggulangan Kejahatan, Jakarta: Prenadamedia Group, 2014. 